\title{
Stochastic Nature and Red Cell Population Distribution of the Sickling-induced $\mathrm{Ca}^{2+}$ Permeability
}

\author{
Virgilio L. Lew, ${ }^{\star}$ Olga E. Ortiz, ${ }^{\ddagger}$ and Robert M. Bookchin ${ }^{\ddagger}$ \\ *Physiological Laboratory, University of Cambridge, Cambridge CB2 EG, United Kingdom; and ${ }^{\ddagger}$ Albert Einstein College of Medicine, \\ New York 10461
}

\begin{abstract}
To explore basic properties of the sickling-induced cation permeability pathway, the $\mathrm{Ca}^{2+}$ component $\left(\mathrm{P}_{\text {sickle-Ca }}\right)$ was studied in density-fractionated sickle cell anemia (SS) discocytes through its effects on the activity of the cells' $\mathrm{Ca}^{2+}$ sensitive $\mathrm{K}^{+}$-channels $\left(\mathrm{K}_{\mathrm{Ca}}\right)$. The instant state of $\mathrm{K}_{\mathrm{Ca}}$ channel activation was monitored during continuous or cyclic deoxygenation of the cells using a novel thiocyanate-densecell formation method. Each deoxy pulse caused a revers-

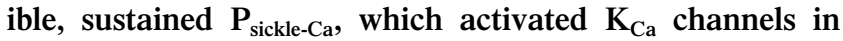
only $10-45 \%$ of cells at physiological $\left[\mathrm{Ca}^{2+}\right]_{0}$ ("activated cells"). After removal of cells activated by each previous deoxy pulse, subsequent pulses generated similar activated cell fractions, indicating a random determination rather than the response of a specific vulnerable subpopulation. The fraction of activated cells rose monotonically with $\left[\mathrm{Ca}^{2+}\right]_{0}$ along a curve reflecting the cells' distribution of $\mathrm{P}_{\text {sickle-Ca, }}$, with values high enough in a small cell fraction to trigger near-maximal $\mathrm{K}_{\mathrm{Ca}}$ channels. Consistent with the stochastic nature of $P_{\text {sickle-Ca }}$, repeated deoxygenated-oxygenated pulsing led to progressive dense cell formation, whereas single long pulses caused one early density shift. Thus deoxygenation-induced $\mathrm{Ca}^{2+}$-permeabilization in $\mathrm{SS}$ cells is a probabilistic event with large cumulative dehydrating potential. The possible molecular nature of $P_{\text {sickle-Ca }}$ is discussed. $(J$. Clin. Invest. 1997. 99:2727-2735.) Key words: $\mathrm{Ca}^{2+}$-activated $\mathrm{K}$-channels $\bullet$ sickle cell anemia - red cells $\bullet$ volume control • $\mathrm{Ca}^{2+}$ permeability
\end{abstract}

\section{Introduction}

The prime trigger of sickle cell dehydration is the reversible formation of a permeability pathway, $\mathrm{P}_{\text {sickle }}$. The pathway is somehow activated or generated by interaction of deoxygenated (deoxy)- $\mathrm{Hb}^{1} \mathrm{~S}$ polymers with red cell membranes, but its nature and precise properties are unknown. $\mathrm{P}_{\text {sickle }}$ is poorly selective for mono and divalent cations (1-6), and is partially in-

A preliminary report of this work was presented at the Biomedicine '97 Meeting in Washington, DC, 25-27 April 1997.

Address correspondence to Robert M. Bookchin, M.D., Albert Einstein College of Medicine, 1300 Morris Park Avenue, Bronx, NY 10461. Phone: 718-430-2123; FAX: 718-904-1164; E-mail: book chin@aecom.yu.edu

Received for publication 15 January 1997 and accepted in revised form 20 March 1997.

J. Clin. Invest.

(C) The American Society for Clinical Investigation, Inc.

0021-9738/97/06/2727/09 \$2.00

Volume 99, Number 11, June 1997, 2727-2735 hibitable by stilbene derivatives (7). The magnitude of its dissipative fluxes is apparently similar, at least for divalent cations, in sickle cell anemia (SS) reticulocytes and mature cells of all densities despite large differences in $\mathrm{Hb} \mathrm{S}$ concentration, extent of polymerization, and sickling morphology (8). The key link between $\mathrm{P}_{\text {sickle }}$ and cell dehydration is calcium. During deoxygenation and sickling of SS red cells, the increase in cell membrane $\mathrm{Ca}^{2+}$ permeability alters the $\mathrm{Ca}^{2+}$-pump-leak steady state, transiently raising $\left[\mathrm{Ca}^{2+}\right]_{\mathrm{i}}$ to levels presumably sufficient to activate $\mathrm{Ca}^{2+}$-sensitive $\mathrm{K}$-channels $\left(\mathrm{K}_{\mathrm{Ca}}\right.$ channels) in some SS cells and trigger their dehydration $(9,10)$. In vivo, the sickling-induced increase in mean $\mathrm{Ca}^{2+}$ permeability is documented by the accumulation of cell calcium in endocytic plasma membrane vesicles, mediated by their inwardly directed $\mathrm{Ca}^{2+}$ pumps (11). But in the absence of information about possible heterogeneity of the sickling-induced $\mathrm{Ca}^{2+}$ permeability $\left(\mathrm{P}_{\text {sickle-Ca }}\right)$, or the effects of elevated $\left[\mathrm{Ca}^{2+}\right]_{\mathrm{i}}$ on the activity of $\mathrm{K}_{\mathrm{Ca}}$ channels, it was not possible to assess the uniformity of cell responses to sickling events or to predict the extent of activation of the $\mathrm{K}_{\mathrm{Ca}}$ channels in the sickled state.

We have attempted here to address some fundamental questions on the properties and possible nature of $\mathrm{P}_{\text {sickle. }}$. Can $\mathrm{K}_{\mathrm{Ca}}$ channel activation be directly demonstrated during a single sickling pulse? If so, are $\mathrm{K}_{\mathrm{Ca}}$ channels activated in all the cells or only in a fraction of cells in each sickling pulse? If only in a fraction, does this response indicate the existence of a vulnerable subpopulation of cells or a probabilistic event randomly affecting different groups of cells in each deoxygenation pulse? Does the response arise from cell to cell differences in $\mathrm{P}_{\text {sickle-Ca }}$ or in other factors controlling $\left[\mathrm{Ca}^{2+}\right]_{\mathrm{i}}$ ? If $\mathrm{P}_{\text {sickle-Ca }}$ is not uniform, how is it distributed? Is $\mathrm{P}_{\text {sickle-Ca }}$ sustained for the duration of the sickling pulse, for part of it, or only during oxydeoxy/deoxy-oxy transitions? To answer these questions we applied an experimental approach originally developed to explore the uniformity of ionophore-induced $\mathrm{Ca}^{2+}$ distributions in normal red cells (12). The method allows detection and separation of subpopulations of red cells with active or inactive $\mathrm{K}_{\mathrm{Ca}}$ channels, with minimal alteration in the $\mathrm{Ca}^{2+}$ distribution which existed within the cells at the time of sampling.

\section{Methods}

Experimental design. The general design was to suspend the selected density fraction of SS cells in their own plasma or other specific media, expose the suspension to alternate deoxy-oxygenated (oxy) pulses in a tonometer, sample cells from oxy and deoxy states, and process the samples in conditions designed to preserve both their original

1. Abbreviations used in this paper: deoxy, deoxygenated; $\mathrm{Hb}$, hemoglobin; Hct, hematocrit; ISC, irreversibly sickled cell; $\mathrm{K}_{\mathrm{Ca}}$ channel, $\mathrm{Ca}^{2+}$-sensitive K-channel; oxy, oxygenated; SCN, thiocyanate; SS, sickle cell anemia, or homozygous hemoglobin $\mathrm{S}$ disease. 
$\mathrm{Ca}^{2+}$ content and state of $\mathrm{K}_{\mathrm{Ca}}$ channel activation, while segregating the cells with active or inactive $\mathrm{K}_{\mathrm{Ca}}$ channels. The SS cell fraction best suited for the present experiments was the normal density fraction, mostly discocytes, because $(a)$ it is light enough to allow cell dehydration to be detected as density shifts; $(b) \mathrm{K}_{\mathrm{Ca}}$ channel-mediated dehydration could be studied with minimal interference from the $\mathrm{K}: \mathrm{Cl}$ cotransport-mediated activity prevalent in the reticulocyte fraction; and $(c)$ it is the most homogeneous and abundant SS cell fraction.

The design of sample processing was based on earlier studies (12) showing that $(a)$ the diffusional permeability of thiocyanate (SCN) anions was at least 20-fold that of $\mathrm{Cl}$ anions; therefore K-permeabilized cells could dehydrate rapidly in low-K, SCN media without ratelimiting effects of the anion; $(b)$ the $\mathrm{Q}_{10}$ of the plasma membrane $\mathrm{Ca}^{2+}$ pump increased sharply from $\sim 4-4.5$ at temperatures between 5 and $37^{\circ} \mathrm{C}$, to $\sim 7-9$ between 0 and $5^{\circ} \mathrm{C}$, so that low temperature could inhibit the Ca-pump and prevent loss of cell $\mathrm{Ca}^{2+}$ in $\mathrm{Ca}^{2+}$-free media; and (c) the temperature sensitivity of $\mathrm{K}_{\mathrm{Ca}}$ channel activation remained low between 0 and $37^{\circ} \mathrm{C}$; therefore cells with active $\mathrm{K}_{\mathrm{Ca}}$ channels, suspended in low-K SCN media at $0-5^{\circ} \mathrm{C}$, would dehydrate to a level similar to the densest sickle cells $(\delta>1.118)$ in $10-30 \mathrm{~min}$. These properties permitted detection of SS cells with active $\mathrm{K}_{\mathrm{Ca}}$ channels by facilitating their selective shrinkage in conditions which minimized postsampling changes in their $\mathrm{Ca}^{2+}$ content and state of $\mathrm{K}_{\mathrm{Ca}}$ channel activation.

Based on this background information, aliquots of the cell suspension were transferred from the tonometer at specified times into a large volume of an ice-cold low-K SCN solution containing sufficient Ca chelator EGTA to ensure its excess over $\left[\mathrm{Ca}^{2+}\right]_{0}$ in the sample. This preserved the $\mathrm{Ca}^{2+}$ content and $\mathrm{K}_{\mathrm{Ca}}$ channel activation state of the cells at the time of sampling by immediately preventing further passive gain or active loss of $\mathrm{Ca}^{2+}$ (see confirmatory evidence in $\mathrm{Re}$ sults). In the ice bath, cells with active $\mathrm{K}_{\mathrm{Ca}}$ channels would shrink and could easily be separated from those with inactive channels by density fractionation. Even if the $\left[\mathrm{Ca}^{2+}\right]_{\mathrm{i}}$ in some of the sampled cells had been just high enough for initial $\mathrm{K}_{\mathrm{Ca}}$ channel activation, as the cells started shrinking in the SCN medium their $\left[\mathrm{Ca}^{2+}\right]_{i}$ would increase and accelerate further shrinkage. This sequence is favored by the minute $\mathrm{Ca}^{2+}$ binding capacity of cytoplasmic $\mathrm{Ca}^{2+}$ buffers in the submicromolar $\left[\mathrm{Ca}^{2+}\right]_{\mathrm{i}}$ range (13-15). Thus even those cells with minimally active $\mathrm{K}_{\mathrm{Ca}}$ channels in the original incubation conditions should be detected by this method. Sampling into SCN media per se promotes cell dehydration by its immediate binding to cell hemoglobin with the consequent increase in impermeant anion concentration, loss of cell $\mathrm{Cl}$, and loss of water $(16,17)$. This effect is relatively small compared to the dehydration power of activated $\mathrm{K}_{\mathrm{Ca}}$ channels, but could contribute to SCN-dense cell formation unrelated to channel activity. To prevent such "noise," and detect only cells which become dense by the activity of their $\mathrm{K}_{\mathrm{Ca}}$ channels, a cut-off relative density of $>1.117$ was chosen to define SCN-dense cells. Preliminary experiments, and those shown below in Figs. 1 and 2, indicated that for SCN-dense cells thus defined, their formation was strictly $\mathrm{Ca}^{2+}$ and deoxygenation dependent, conditions exclusive to $\mathrm{K}_{\mathrm{Ca}}$ channel activation.

Experimental procedure. Heparinized venous blood was obtained from sickle cell anemia patients and normal controls after informed consent. The red cells were washed three times with solution A containing $(\mathrm{mM}): 135 \mathrm{NaCl}, 5 \mathrm{KCl}, 10 \mathrm{Na}$-phosphate buffer $(\mathrm{pH}$ 7.4), 11 glucose, osmolality $=291 \mathrm{mosmol} /$ liter. The buffy coat of white blood cells and the top layer of light, reticulocyte-rich red cells were removed with each wash. Preliminary tests indicated that this procedure eliminated most cells with $\delta<1.095$. The remaining cells were suspended at about 10\% hematocrit (Hct) in solution A and layered over arabinogalactan media of relative density 1.106 , prepared as described previously (18). After centrifugation for $15 \mathrm{~min}$ at 17,000 rpm in a Sorvall RC2B (DuPont Company, Wilmington, DE) with a fixed angle rotor, the dense cell pellet (containing mostly irreversibly sickled cells) was discarded. The remaining cells (initially $\delta \leq 1.106$ ), mostly discocytes, were washed twice more in solution A containing, in addition, $50 \mu \mathrm{M}$ EGTA, and then either used immediately or kept overnight at $4^{\circ} \mathrm{C}$, supplemented with $3 \mathrm{mM}$ adenine and $10 \mathrm{mM}$ inosine. After two additional washes (for cells stored overnight), the cells were suspended at between 8 and $40 \%$ Hct in plasma or in one of the following media: solution $\mathrm{B}(\mathrm{mM}): \mathrm{NaCl}, 135 ; \mathrm{KCl}, 5$; Hepes-Na, pH 7.40 at $37^{\circ} \mathrm{C}, 10$; solution C: NaSCN, $135 ; \mathrm{KCl}, 5$; Hepes-Na, pH 7.40 at $37^{\circ} \mathrm{C}, 10$. When indicated in figure legends, these solutions were supplemented with $3 \mathrm{mM}$ adenine, $10 \mathrm{mM}$ inosine, $10 \mathrm{mM}$ glucose, and EGTA or $\mathrm{CaCl}_{2}$. The cell suspensions were equilibrated in a tonometer (model 237; Instrumentation Laboratory, Inc., Lexington, MA) at $37^{\circ} \mathrm{C}$ with either air or argon saturated with water vapor at $37^{\circ} \mathrm{C}$ (for oxy and deoxy conditions, respectively). When the cells were suspended in autologous plasma, the gases also contained $5.6 \%$ $\mathrm{CO}_{2}$. The suspension $\mathrm{pH}$ was monitored using a PHM $71 \mathrm{MK} 2$ meter (Radiometer, Copenhagen, Denmark) and a glass microcapillary electrode unit, type E5021, and kept within the range of 7.36-7.48 by addition, when required, of small volumes of $0.15 \mathrm{M} \mathrm{HCl}^{\text {or }} \mathrm{NaHCO}_{3}^{-}$.

At the times shown in the figures, $0.1-\mathrm{ml}$ samples of the cell suspension were delivered to microfuge tubes containing $0.9 \mathrm{ml}$ of icecold SCN medium containing (mM): $138 \mathrm{NaSCN}, 2 \mathrm{KCl}, 10$ Hepes$\mathrm{Na}, \mathrm{pH} 7.4$, and $1 \mathrm{Na}-\mathrm{EGTA}$. After 10-30 min of incubation in the ice bath, $0.3-0.4 \mathrm{ml}$ of arabinogalactan medium, $\delta=1.118$, was gently delivered underneath the sample, using a syringe and long needle, and the tube was spun in an Eppendorf microfuge for 5 min $(12,000 \mathrm{rpm})$ at room temperature. Any departures from these procedures are specifically noted in the figure legends. Hemoglobin concentrations were measured after conversion to cyanmethemoglobin using Drabkin's solution. The fraction of dense cells formed in all conditions was calculated from the ratio of hemoglobin content in dense cell pellets to total hemoglobin in the original samples, corrected for any hemolysis by subtracting the supernatant hemoglobin concentrations of original samples (usually $<2 \%$ ).

Loading of red cells with the $\mathrm{Ca}^{2+}$ chelator benz2 and measurements of their $\mathrm{Ca}^{2+}\left({ }^{45} \mathrm{Ca}\right)$ uptake were performed as previously described $(9,14,19)$.

To measure ${ }^{86} \mathrm{Rb}$ influx, the tracer was added to the cells in the tonometer. The cell ${ }^{86} \mathrm{Rb}$ content was measured before and after SCN-density separation, and expressed in mmol per $340 \mathrm{~g}$ of $\mathrm{Hb}$, using the specific activity of the tracer relative to the $\mathrm{K}$ concentration in the medium in which the cells were suspended, as described (18).

\section{Results}

Effects of deoxygenation and calcium on generation of SCNdense cells. The experiment of Fig. $1 A$ examined the fraction of SS discocytes which become dense when they are suspended in autologous plasma, exposed to oxy-deoxy periods shown in the figure, and sampled at 10 -min intervals into cold SCN medium (see Methods). We see that these SCN-dense cells were formed only from samplings during deoxygenation periods, that their proportion increased during the first 20-30 min of deoxygenation, and that their formation was fully prevented by either reoxygenation or by addition of excess EGTA before sampling the deoxygenated cells. In the experiment of Fig. $1 B$, cells from the same batch were suspended in a $\mathrm{Ca}^{2+}$-free plasmalike Cl-buffer. Again, neither deoxygenation in the absence of $\mathrm{Ca}^{2+}$ nor presence of $\mathrm{Ca}^{2+}$ in oxy states generated $\mathrm{SCN}$ dense cells, but addition of $\mathrm{Ca}^{2+}$ to deoxy-cell suspension states promptly triggered the formation of SCN-dense cells. The results in Fig. 1 thus indicate that SCN-dense cell formation occurs only with cells sampled in the deoxygenated state, is strictly dependent on the presence of external $\mathrm{Ca}^{2+}$, and is abolished on reoxygenation. Furthermore, $\mathrm{P}_{\text {sickle-Ca }}$ activation persisted throughout deoxygenation, not just during oxydeoxy transitions. The strict $\mathrm{Ca}^{2+}$ dependence of SCN-dense 
A

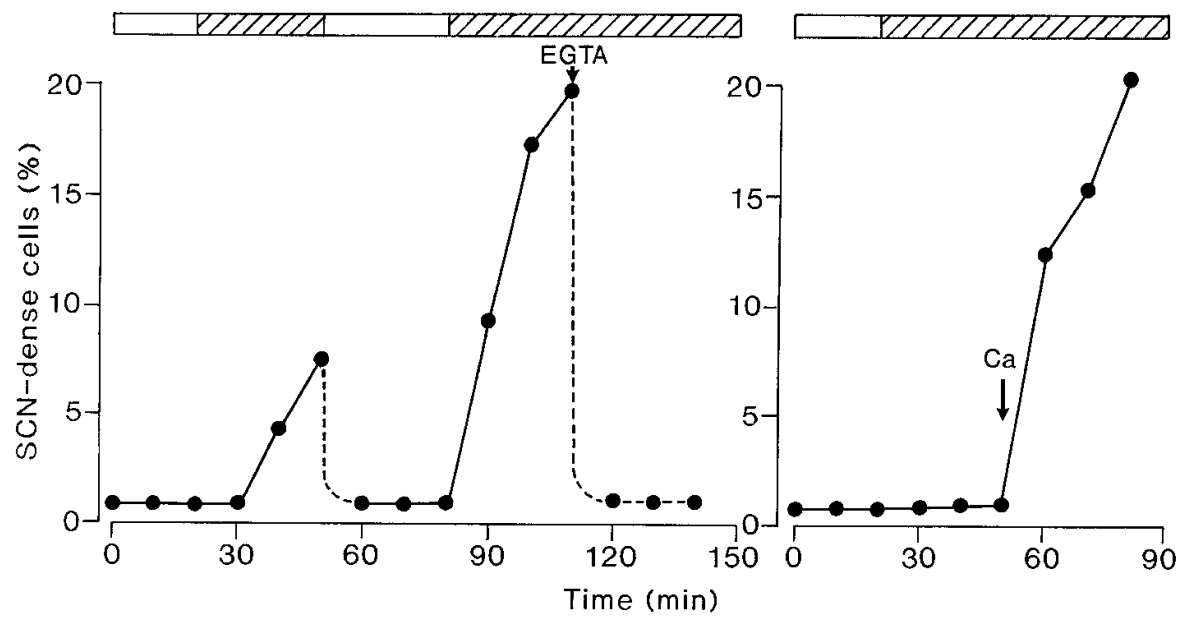

Figure 1. Effects of deoxygenation and calcium on SCN-dense cell formation. $(A)$ SS discocytes were suspended at $20 \%$ Hct in autologous plasma supplemented with 3 $\mathrm{mM}$ adenine and $10 \mathrm{mM}$ inosine, and equilibrated at $37^{\circ} \mathrm{C}$ in the tonometer for the deoxy (striped bars) and oxy (open bars) periods shown in the horizontal bars. Samples were taken every 10 min to measure the fraction of cells that became dense during subsequent incubation in cold SCN medium (see Methods). NaOH-neutralized EGTA (final concentration $3 \mathrm{mM}$ ) was added as shown. $(B)$ SS discocytes from the same batch were suspended at $20 \%$ Hct in solution B with adenine, inosine, and $50 \mu \mathrm{M} \mathrm{Na-EGTA.} \mathrm{At} \mathrm{the} \mathrm{time}$ shown, $\mathrm{CaCl}_{2}$ (final concentration $1.6 \mathrm{mM}$ ) was added. Similar results were obtained in six additional experiments with blood from four different donors. cell formation shows that neither the well-characterized dehydrating effects of SCN (16) nor any residual $\mathrm{K}: \mathrm{Cl}$ cotransport activity in the discocytes was sufficient to generate dehydration to the levels determined by this method $(\delta>1.118)$.

The continuing increase in SCN-dense cells during the first 30 min of deoxygenation in the presence of $\left[\mathrm{Ca}^{2+}\right]_{\mathrm{o}}$ (Fig. 1, A and $B$ ) raised the question of whether all the cells would eventually be similarly activated. Fig. $2 A$ shows that with a single long deoxy pulse, $\sim 20 \%$ SCN-dense cells were generated within 20 min of deoxygenation, with no further increase. Fig. $2 B$ shows that each of two consecutive deoxy pulses (separated by an oxy period) generated $\sim 40 \%$ SCN-dense cells within $30 \mathrm{~min}$, with no further increase during the rest of each deoxy pulse. In other similar experiments where SS discocytes were suspended either in plasma or in plasmalike Cl-buffers, the plateau fractions of SCN-dense cells were between 10 and $46 \%$, with similar consistency in consecutive pulses on the same suspension. Thus, with physiological $\left[\mathrm{Ca}^{2+}\right]_{0}(1.0-1.2$

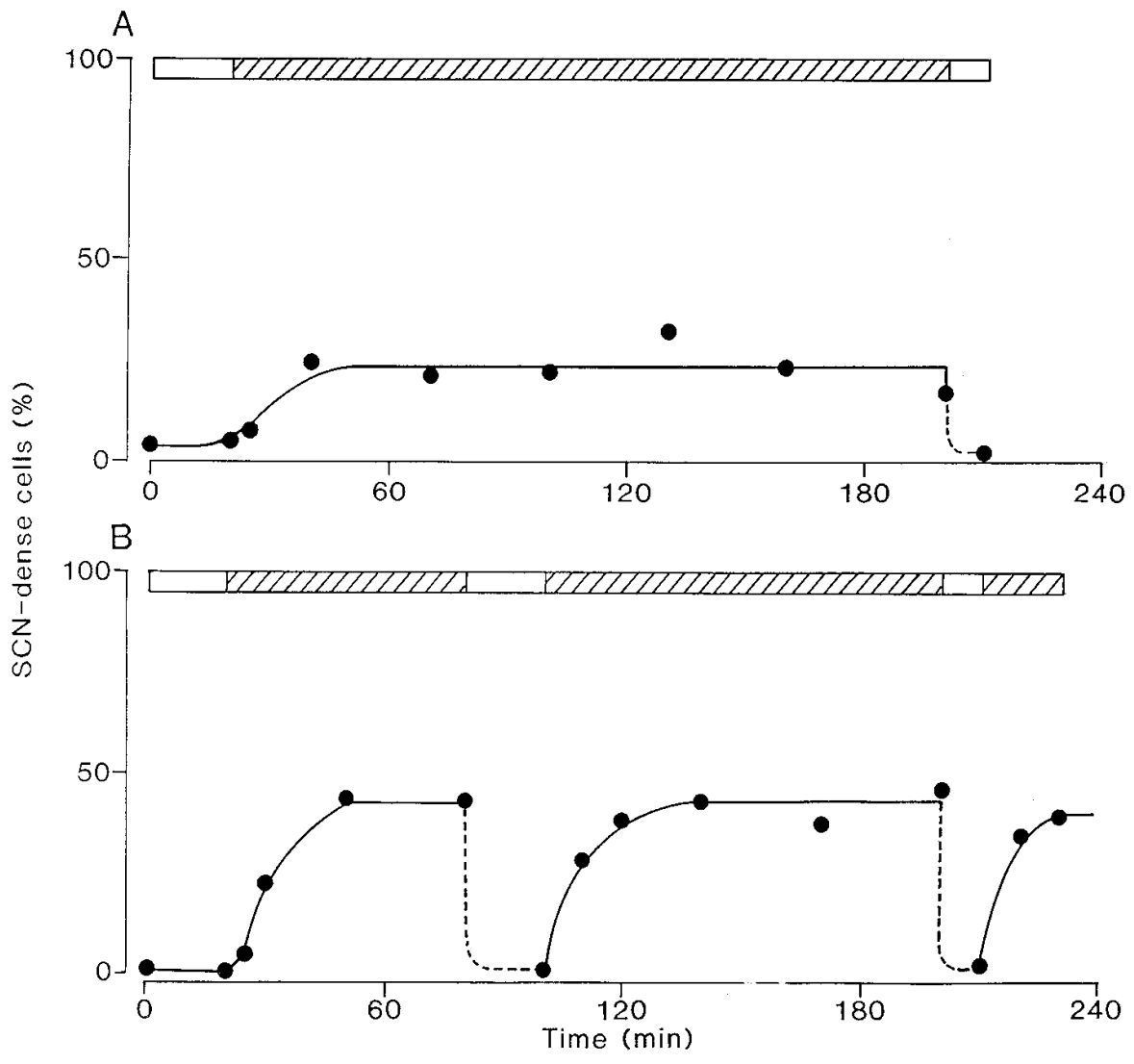

Figure 2. Generation of SCN-dense cells during prolonged and consecutive deoxygenation pulses. SS discocytes from a single density-fractionation were suspended in autologous plasma supplemented with adenine and inosine at Hct of $8 \%(A)$ or $16 \%(B)$, and equilibrated in the tonometer at $37^{\circ} \mathrm{C}$ for the deoxy and oxy periods shown (as in Fig. 1). Samples were taken every $10 \mathrm{~min}$ to measure the fraction of cells that became dense during subsequent incubation in cold SCN medium. Experiments $A$ and $B$ were run consecutively. The similar plateau fractions of SCN-dense cells formed with consecutive deoxy pulses on a single cell suspension $(B)$ were also seen in four similar experiments. But sequential experiments with the same cells (suspended at different Hct) sometimes showed large variations in plateau fractions of SCN-dense cells (compare $A$ and $B$ ). 
$\mathrm{mM}$ ), stable fractions of SCN-dense cells were generated within the first 20-30 min of each deoxy pulse, with plateau levels $(<50 \%)$ which differed between experiments but were similar for consecutive deoxy pulses with the same cell suspension.

Next, we considered why only a minority of SS discocytes became SCN-dense during each deoxy pulse, and why the plateau levels recurred with consecutive pulses. Were these cells a particularly vulnerable subpopulation, with the same cells affected with each pulse, or was each pulse generating different SCN-dense cells at random, with a similar probability? To address this question, we removed the cells that had become dense during one deoxy pulse and then tested whether subsequent pulses would generate additional SCN-dense cells (Fig. $3)$. Separation of dense cells from sequential deoxy pulses required suspension of the cells in the tonometer in the SCN buffer. It is important to point out that preliminary experiments under these conditions (not shown) demonstrated that $\mathrm{SCN}$-dense cells were generated from SS discocytes only on deoxygenation in the presence of $\mathrm{Ca}^{2+}$, and that normal $\mathrm{Hb}$ red cells exposed to the same experimental maneuvers did not form SCN-dense cells, just as when the cells in the tonometer were suspended in plasma or $\mathrm{Cl}$ media.

We see that, despite incomplete removal of dense cells from previous pulses, successive sickling pulses recruited new cohorts of dense cells, each similar in size to the initial cohort (Fig. 3). Thus, most of the SS discocytes, when sickled in the presence of $\mathrm{Ca}^{2+}$, could become dense in SCN media. The similar proportion of new SCN-dense cells in successive pulses indicates that their generation is a random probabilistic event for each cell each time it is deoxygenated. A negative response to an earlier deoxy pulse does not influence its probability of becoming SCN-dense in a subsequent pulse, with the exception of F-cells. The percentage of $\mathrm{Hb}$ F in SCN-dense cells was 12 $30 \%$ less than that in the original sample, reflecting their expected lower probability of becoming SCN-dense than non-F discocytes.

What determines these probabilities? The clear $\mathrm{Ca}^{2+} \mathrm{de}-$

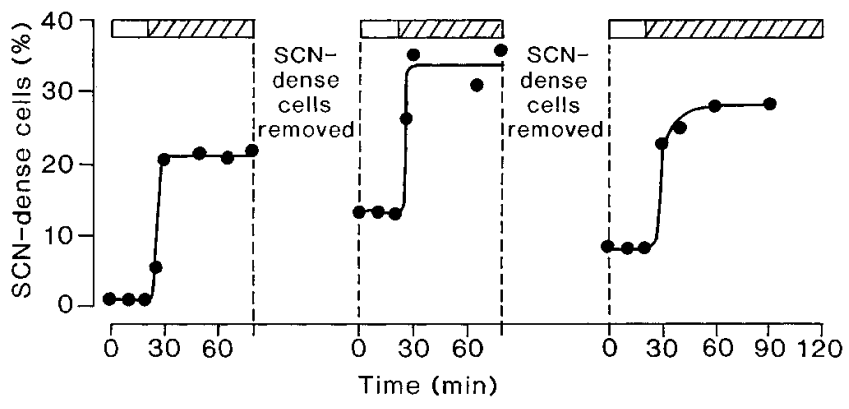

Figure 3. Effect of removing the SCN-dense cells formed in one deoxy pulse on the fraction formed in the next pulse. SS discocytes were suspended at $30 \% \mathrm{Hct}$ in solution $\mathrm{C}$ (with SCN anion) supplemented with adenine, inosine, and $1.6 \mathrm{mM} \mathrm{CaCl}_{2}$. Samples were taken every $10 \mathrm{~min}$ to measure the fraction of cells that became dense $(\delta>1.118)$. After $30 \mathrm{~min}$ of deoxy, the whole suspension was layered on arabinogalactan media $(\delta=1.118)$ in several microfuge tubes, and after a 5 -min spin at $12,000 \mathrm{rpm}$, the cells with $\delta<1.118$ were washed and resuspended in solution $\mathrm{C}$ at $30 \% \mathrm{Hct}$ in the tonometer, and the deoxygenation cycle was repeated. The third deoxygenation cycle was for $40 \mathrm{~min}$. Similar results were obtained in another experiment. pendence of SCN-dense cell formation points to factors controlling the $\mathrm{K}_{\mathrm{Ca}}$ channel activity of each cell, including $\left[\mathrm{Ca}^{2+}\right]_{\mathrm{i}}$ (as determined by $\mathrm{P}_{\text {sickle-Ca }}$ and $\mathrm{Ca}^{2+}$ pump activity), the number of $\mathrm{K}_{\mathrm{Ca}}$ channels, and their $\mathrm{Ca}^{2+}$-sensitivity. The similar fraction of SCN-dense cells formed in successive pulses (Fig. 3), together with the knowledge that those cells have varied levels of $\mathrm{K}_{\mathrm{Ca}}$ channel activation in the tonometer (see Methods), suggests that cell-to-cell differences in the number and $\mathrm{Ca}^{2+}$ sensitivity of the $\mathrm{K}_{\mathrm{Ca}}$ channels have little or no influence on the fraction of SCN-dense cells. The pump-leak steady state $\left[\mathrm{Ca}^{2+}\right]_{i}$ level in each deoxy cell reflects the balance between $\mathrm{P}_{\text {sickle-Ca }}$ and $\mathrm{Ca}^{2+}$ pump-mediated fluxes. Earlier studies showed that $\mathrm{P}_{\text {sickle-Ca }}$ elicits the elevated $\left[\mathrm{Ca}^{2+}\right]_{\mathrm{i}}$ of deoxy-SS cells. Therefore, the main stochastic event determining the fraction of SCN-dense cells with each deoxy pulse must be the extent of the cation-permeabilizing polymer-membrane interaction, which determines $\mathrm{P}_{\text {sickle-Ca. According to this analysis, each }}$ time a cohort of SS cells is deoxygenated, their $\mathrm{P}_{\text {sickle-Ca }}$ varies randomly, following a certain probability distribution among most of the cells.

The distribution of $\mathrm{P}_{\text {sickle-Ca }}$ could be explored further by varying $\left[\mathrm{Ca}^{2+}\right]_{0}$ levels, to test whether more cells become SCNdense as $\left[\mathrm{Ca}^{2+}\right]_{\mathrm{o}}$ is increased. For at low $\left[\mathrm{Ca}^{2+}\right]_{\mathrm{o}}$, those cells with the highest $\mathrm{P}_{\text {sickle-Ca }}$ would gain enough $\mathrm{Ca}^{2+}$ for $\mathrm{K}_{\mathrm{Ca}}$ channel activation, whereas at sufficiently high $\left[\mathrm{Ca}^{2+}\right]_{\mathrm{o}}$ even those cells with low $\mathrm{P}_{\text {sickle-Ca }}$ could become SCN-dense. We therefore explored the increase in $\mathrm{SCN}$-dense cells over a wide range of increasing $\left[\mathrm{Ca}^{2+}\right]_{0}$.

Two similar experiments (Fig. 4, $A$ and $C$ ) show that increasing $\left[\mathrm{Ca}^{2+}\right]_{\mathrm{o}}$ generated progressively higher plateau fractions of SCN-dense cells. These plateaus are plotted as a function of $\left[\mathrm{Ca}^{2+}\right]_{\mathrm{o}}$ in Fig. $4, B$ and $D$, and show a steep, nearly linear dependence on $\left[\mathrm{Ca}^{2+}\right]_{\mathrm{o}}$ at $\left[\mathrm{Ca}^{2+}\right]_{\mathrm{o}}<2 \mathrm{mM}$, followed by a leveling off at $\left[\mathrm{Ca}^{2+}\right]_{\mathrm{o}}>5 \mathrm{mM}$. Thus each sickling pulse appears to generate a wide range of $\mathrm{P}_{\text {sickle-Ca }}$ among the SS discocytes, with a continuous distribution and a slope which rises most steeply over physiological $\left[\mathrm{Ca}^{2+}\right]_{\mathrm{o}}$ values $(\sim 1.0-1.2 \mathrm{mM})$. At those physiological $\left[\mathrm{Ca}^{2+}\right]_{0}$ levels, the $\mathrm{P}_{\text {sickle-Ca }}$ of most SS discocytes (55-90\% in different experiments) were too low to activate $\mathrm{K}_{\mathrm{Ca}}$ channels. But at least $70 \%$ of SS discocytes exhibited some increased $\mathrm{Ca}^{2+}$ permeability, since they became SCN-dense at high $\left[\mathrm{Ca}^{2+}\right]_{\mathrm{o}}$.

Test for saturation of $\mathrm{Ca}^{2+}$ influx through $P_{\text {sickle-Ca}}$. The leveling off of SCN-dense cells at $\left[\mathrm{Ca}^{2+}\right]_{\mathrm{o}}>5 \mathrm{mM}$ (Fig. 4) could reflect either little further increase in $\mathrm{P}_{\text {sickle-Ca }}$ in $20-30 \%$ of cells (the tail end of the $\mathrm{P}_{\text {sickle-Ca }}$ distribution) or saturation of $\mathrm{Ca}^{2+}$ influx through $\mathrm{P}_{\text {sickle-Ca. }}$ To distinguish between these two possibilities, the mean initial $\mathrm{Ca}^{2+}$ influx into chelator-containing SS discocytes was measured as a function of $\left[\mathrm{Ca}^{2+}\right]_{\mathrm{o}}$ in oxy and deoxy conditions (Fig. 5). Since $\mathrm{Ca}^{2+}$ is distributed unevenly among the cells because of their different $\mathrm{P}_{\text {sickle-Ca, }}$, the interpretation of $\mathrm{Ca}^{2+}$ influx results from measured mean cell calcium uptake is quite complex (see Discussion). But the question of whether the leveling off of the fraction of SCN-dense cells at $\left[\mathrm{Ca}^{2+}\right]_{\mathrm{o}}>5 \mathrm{mM}$ results from saturation of $\mathrm{Ca}^{2+}$ uptake through $\mathrm{P}_{\text {sickle-Ca }}$ can be addressed by observing how $\mathrm{Ca}^{2+}$ influx varies with $\left[\mathrm{Ca}^{2+}\right]_{\mathrm{o}}$ at high $\left[\mathrm{Ca}^{2+}\right]_{\mathrm{o}}$. Fig. 5 confirms $(20,21)$ that deoxygenation causes a marked increase in $\mathrm{P}_{\text {sickle-Ca }}$ of SS discocytes, and shows in addition that their $\mathrm{Ca}^{2+}$ influx continues to increase at $\left[\mathrm{Ca}^{2+}\right]_{\mathrm{o}}>5 \mathrm{mM}$, without saturating at 16 $\mathrm{mM}$, the highest level tested here. Thus, the leveling off of SCN-dense cell formation at high $\left[\mathrm{Ca}^{2+}\right]_{\mathrm{o}}$ (Fig. 4, $B$ and $D$ ) ap- 

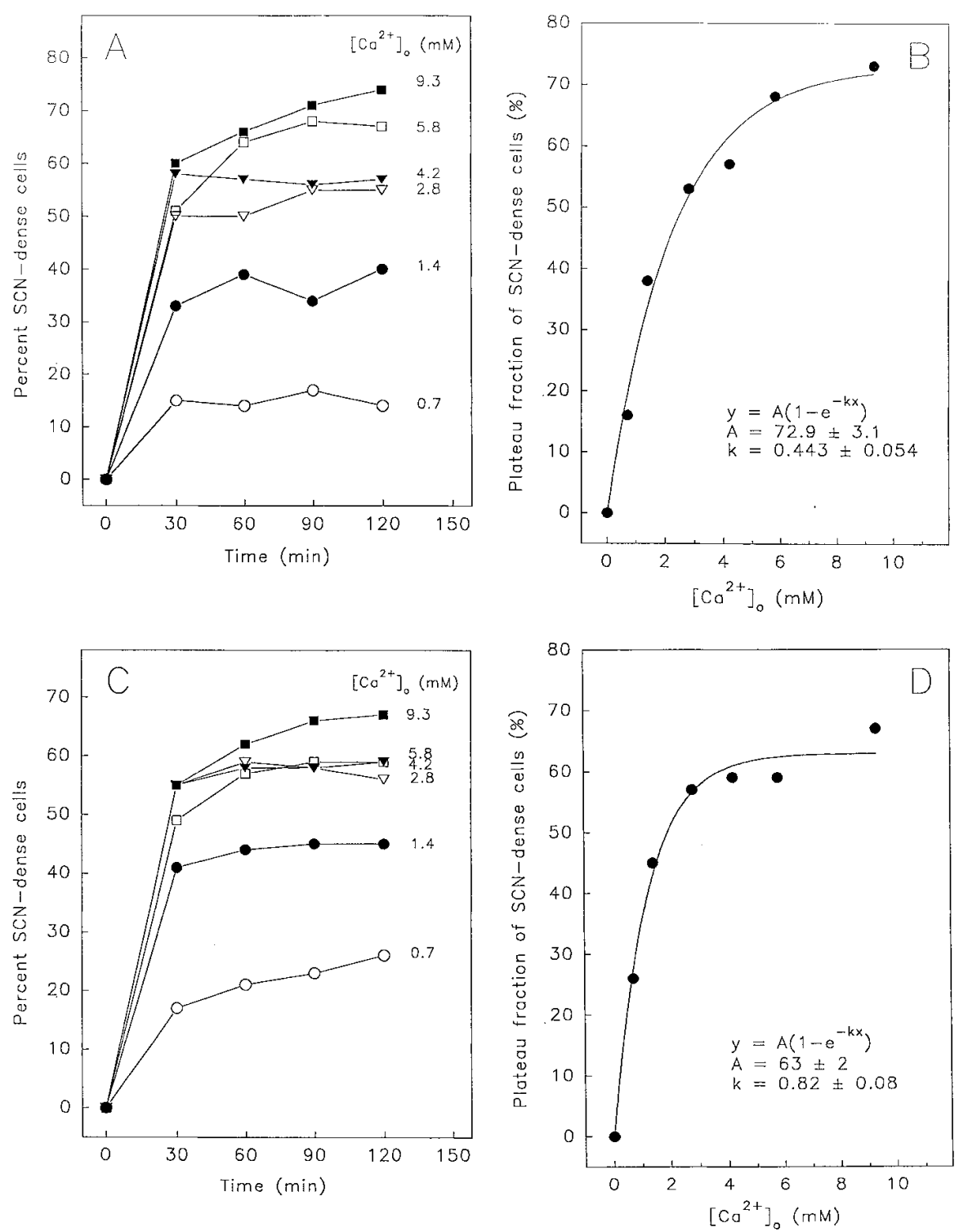

Figure 4. Effect of increasing external $\mathrm{Ca}^{2+}$ on SCN-dense cell formation. $A$ and $B$, and $C$ and $D$ show two experiments with cells from different donors. SS discocytes were suspended at $40 \%$ Hct in solution B supplemented with $10 \mathrm{mM}$ inosine, $10 \mathrm{mM}$ glucose, and $50 \mu \mathrm{M}$ EGTA. After $30 \mathrm{~min}$ of deoxy at $37^{\circ} \mathrm{C}$ in the tonometer, 1-ml aliquots were transferred under argon to six vials, each containing deoxy solution $\mathrm{B}$ supplemented with $\mathrm{CaCl}_{2}$ to give the final medium $\mathrm{Ca}^{2+}$ concentrations shown. The cells were magnetically stirred under argon for $120 \mathrm{~min} . t=0$ corresponds to the time just before transfer of cells to the calciumcontaining vials. $A$ and $C$ show the SCNdense cells at the sampling times, at each level of $\left[\mathrm{Ca}^{2+}\right]_{0}$. Quasi-plateau values were estimated as means of the last two, three, or four samples between 30 and $120 \mathrm{~min}$, depending on when the points leveled off. These estimated plateaus are plotted as a function of $\left[\mathrm{Ca}^{2+}\right]_{\mathrm{o}}$ in $B$ and $D$, where the lines represent the best exponential fit of the experimental curve obtained by least mean squares. The parameters are shown in the figure. parently results from the $\mathrm{P}_{\text {sickle-Ca }}$ distribution among the cells, rather than from limiting $\mathrm{Ca}^{2+}$ influx through $\mathrm{P}_{\text {sickle-Ca. The re- }}$ sults in Fig. 4 reflect the distribution of $\mathrm{P}_{\text {sickle-Ca }}$ values generated by full deoxygenation of SS discocytes, and suggest that a substantial fraction, albeit a minority, of SS discocytes deoxygenated at physiological (and even lower) levels of $\left[\mathrm{Ca}^{2+}\right]_{\mathrm{o}} \mathrm{de}-$ velop sufficiently high $\mathrm{P}_{\text {sickle-Ca }}$ (and therefore $\left[\mathrm{Ca}^{2+}\right]_{\mathrm{i}}$ elevations) to activate their $\mathrm{K}_{\mathrm{Ca}}$ channels, as demonstrated by the generation of SCN-dense cells. Sickling-induced $\mathrm{Ca}^{2+}$ influx is therefore extremely heterogeneous among the cells. If the mean $\mathrm{Ca}^{2+}$ influx values reported in Fig. 5 are attributed to the small fractions of cells that become SCN-dense at low or physiological $\left[\mathrm{Ca}^{2+}\right]_{\mathrm{o}}$ levels, those cells must have very high $\mathrm{Ca}^{2+}$ influx values of $>1 \mathrm{mmol} /(340 \mathrm{~g} \mathrm{Hb} / \mathrm{h})$, fluxes which have been shown to generate dense normal-Hb cells within a few hours of $\mathrm{Ca}^{2+}$ permeabilization with the ionophore A23187 (10). Thus the results in Figs. 3-5 demonstrate that each sickling episode randomly generates small populations of cells with high $\mathrm{Ca}^{2+}$ permeabilities, and sufficient $\mathrm{Ca}^{2+}$ influx to raise $\left[\mathrm{Ca}^{2+}\right]_{\mathrm{i}}$ to levels producing substantial $\mathrm{K}_{\mathrm{Ca}}$ channel activation. In some cells the activation of $\mathrm{K}_{\mathrm{Ca}}$ channels may be nearmaximal, so that cell dehydration becomes limited by the diffusional $\mathrm{Cl}$ permeability $\left(\mathrm{P}_{\mathrm{Cl}}\right)$.

The mean $\mathrm{Ca}^{2+}$ influx was also measured in dense SS cells fractions (rich in irreversibly sickled cells [ISC]) with the incorporated $\mathrm{Ca}^{2+}$-chelator benz2. The results of two such experiments were similar, and one is included in Fig. 5. No significant differences in mean $\mathrm{Ca}^{2+}$ uptakes were seen between fully deoxy dense cells (ISC) and discocytes, suggesting that the morphological differences in polymer structure and concentration between these two cell fractions $(22,23)$ may not be relevant determinants of $\mathrm{P}_{\text {sickle-Ca}}$.

Sickling-induced dehydration of SS discocytes in Cl media, without $S C N$ processing. It was important to ascertain whether the properties of $\mathrm{P}_{\text {sickle-Ca }}$ inferred from analysis of SCN-dense cell formation directly reflected those of the original cell suspensions in the tonometer. The observed $\mathrm{Ca}^{2+}$ dependence, distribution, and stochastic nature of $\mathrm{P}_{\text {sickle-Ca }}$ predict that cell 


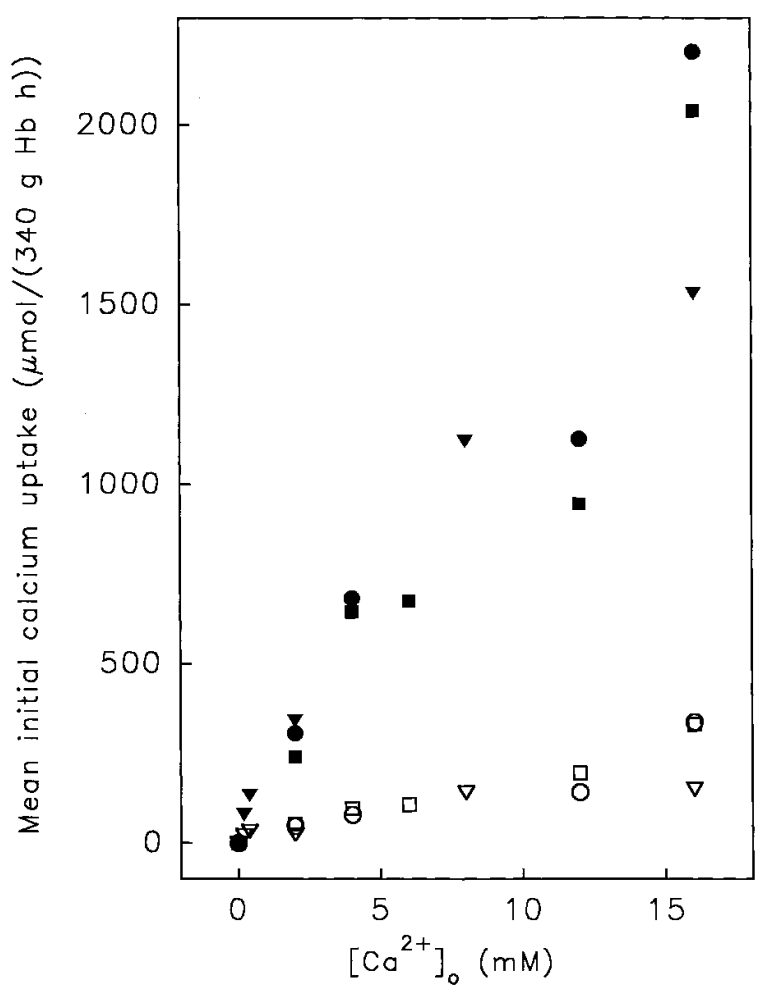

Figure 5. Effects of deoxygenation and varying external $\mathrm{Ca}^{2+}$ on mean initial $\mathrm{Ca}^{2+}\left({ }^{45} \mathrm{Ca}\right)$ influx in SS cell fractions. SS discocytes from two donors were loaded with benz2 to chelate incoming $\mathrm{Ca}^{2+}$ and prevent activation of the $\mathrm{Ca}^{2+}$ pump and $\mathrm{K}_{\mathrm{Ca}}$ channel, and $\mathrm{Ca}^{2+}\left({ }^{45} \mathrm{Ca}\right)$ influx was measured as previously described $(9,19)$. Cells suspended at $10 \%$ Hct in solution B supplemented with inosine and pyruvate were equilibrated in the tonometer at $37^{\circ} \mathrm{C}$, oxy or deoxy. Initial calcium uptake was estimated from the $\mathrm{Ca}^{2+}\left({ }^{45} \mathrm{Ca}\right)$ gained by the cells in the first 4 min after addition of $\mathrm{Ca}^{2+}\left({ }^{45} \mathrm{Ca}\right)$ to the medium, and expressed as hourly uptake rates. Open symbols, oxy; filled symbols, deoxy. Triangles and circles correspond to SS discocytes from the two donors. The squares show the mean initial calcium uptake by a dense, ISC-rich cell fraction $(\delta>1.118)$ from the same donor as that of triangles.

dehydration should be more intense the higher the medium $\mathrm{Ca}^{2+}$ concentration, and more sustained the higher the frequency of oxy-deoxy cycles. Since each deoxy pulse generates a new fraction of cells with high $\mathrm{P}_{\text {sickle-Ca }}$, the cumulative effect of frequent and short deoxy pulses should ultimately generate more dense cells than a single long pulse or less frequent long pulses over equivalent periods.

In Fig. 6, the density shifts occurring with cells suspended in $\mathrm{Cl}$ media during a single long deoxy pulse are compared with those induced by alternating 20 min deoxy-5 min oxy pulses over a similar long period. Frequent deoxy-oxy cycling generated cumulative shifts towards higher densities, with larger shifts at the higher $\left[\mathrm{Ca}^{2+}\right]_{0}$ concentration (Fig. $6 \mathrm{~A}$ ) and a progressive increase over time in the fraction of cells with density $(\delta)>1.118$ (Fig. $6 \mathrm{~B}$ ). The two panels in Fig. $6 C$ illustrate the difference in patterns of density shifts elicited by a single pulse and by frequent pulses. A sustained long deoxy pulse generated a single, early, and limited density shift which leveled off within an hour (bottom panel), whereas short, frequent deoxy-oxy pulses produced cumulative density shifts, as expected from high $\mathrm{P}_{\text {sickle-Ca }}$ generation in cells newly activated with each pulse. These results therefore demonstrate that the effects predicted from analysis of the properties of SCN-dense cell formation are indeed obtained for SS cells suspended in physiological saline and exposed to deoxy-oxy pulses in the tonometer.

Effect of deoxygenation on ${ }^{86} \mathrm{Rb}$ influx in $\mathrm{SCN}$-dense cells. Another experimental approach was used to test more directly for the presence of a small fraction of deoxy SS cells with nearmaximal $\mathrm{K}_{\mathrm{Ca}}$ channel activation, with rates of dehydration limited by $\mathrm{P}_{\mathrm{Cl}}$. If sickling in $\mathrm{Ca}^{2+}$-containing plasma or plasma-like $\mathrm{Cl}$ media increased their $\mathrm{K}$ permeability so that $\mathrm{P}_{\mathrm{K}}$ substantially exceeded $\mathrm{P}_{\mathrm{Cl}}$, those cells should be hyperpolarized. This hyperpolarization could be further increased by reducing the external $\mathrm{K}$ levels below normal. ${ }^{86} \mathrm{Rb}$ tracer added to this low $\mathrm{K}$ medium should accumulate preferentially in the most K-permeabilized, highly hyperpolarized cells, due to the strong inward driving force on the ${ }^{86} \mathrm{Rb}$ influx (described as a countertransport-like effect in such K-permeabilized cells [24]). Thus a $\mathrm{Ca}^{2+}$-dependent, sickling-induced increase in ${ }^{86} \mathrm{Rb}$-tracer influx might be evident only in the cells which become dense after SCN treatment. Even though a large fraction of the combined $\left(\mathrm{K}+{ }^{86} \mathrm{Rb}\right)$ content of these cells may be lost during $\mathrm{SCN}$-induced shrinkage, the ${ }^{86} \mathrm{Rb} / \mathrm{K}$ specific activity would be highest in these cells; and since ${ }^{86} \mathrm{Rb}$ influx through $\mathrm{P}_{\text {sickle }}$ is minimized by the low external $\mathrm{K}$ concentration, the higher countertransport-driven influx might exceed the "noise level" of the ${ }^{86} \mathrm{Rb}$-influx into all other nonhyperpolarized cells.

Indeed, such an experiment (Fig. 7) showed that a sicklinginduced increase in ${ }^{86} \mathrm{Rb}$ uptake was detectable only in the presence of $\left[\mathrm{Ca}^{2+}\right]_{\mathrm{o}}$, and limited to the cells which subsequently became dense in SCN media. Thus a fraction of the cells that became dense in SCN must have had their $\mathrm{K}_{\mathrm{Ca}}$ channels almost fully activated during incubation in a $\mathrm{Cl}$ medium in the tonometer, when they were sickled in the presence of $\left[\mathrm{Ca}^{2+}\right]_{0}$.

\section{Discussion}

To characterize the intermediate steps leading to SS discocyte dehydration in vivo, we investigated their volume responses to deoxygenation. The results indicated that $(a)$ each deoxy pulse caused a reversible increase in $\mathrm{Ca}^{2+}$ permeability, $\mathrm{P}_{\text {sickle-Ca, }}$, which lasted for the duration of the pulse; $(b)$ the presence of external $\mathrm{Ca}^{2+}$ caused $\mathrm{K}_{\mathrm{Ca}}$ channel activation in a fraction of cells (activated cells); $(c)$ the fraction of activated cells increased within $\sim 30$ min to plateau values between 10 and $45 \%$ in different experiments at physiological external $\mathrm{Ca}^{2+}$ concentrations; $(d)$ the plateau was constant for at least $3 \mathrm{~h}$, and of similar value in consecutive pulses; $(e)$ the fraction of activated cells was determined randomly in each pulse and did not reflect the response of a particularly vulnerable subpopulation of cells; $(f)$ the plateau fraction of activated cells increased monotonically with $\left[\mathrm{Ca}^{2+}\right]_{\mathrm{o}}$ along a curve which reflected the distribution of $\mathrm{P}_{\text {sickle-Ca }}$ in the cell population; this distribution indicated that the $\mathrm{P}_{\text {sickle-Ca }}$ generated in each deoxy pulse varied widely among the cells, with the majority of cells having a value too low for $\mathrm{K}_{\mathrm{Ca}}$ channel activation at physiological $\left[\mathrm{Ca}^{2+}\right]_{\mathrm{o}} ;(\mathrm{g})$ as expected from the stochastic nature of $\mathrm{P}_{\text {sickle-Ca, }}$, frequent deoxy-oxy pulsing was more efficient in generating larger fractions of dense cells than single deoxygenation pulses; and $(h)$ in the fraction of cells with the highest $\mathrm{P}_{\text {sickle-Ca }}$ 

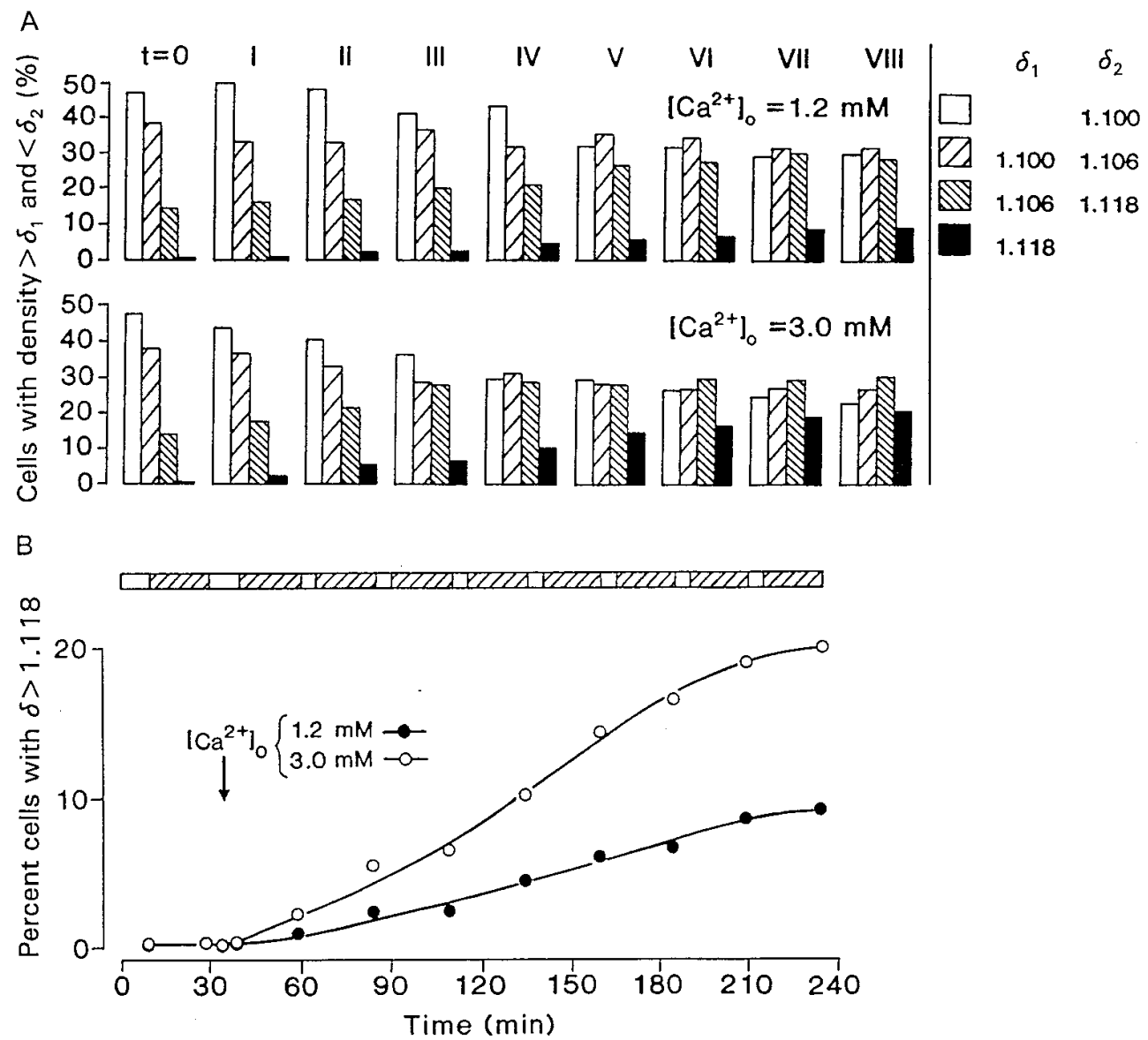

C

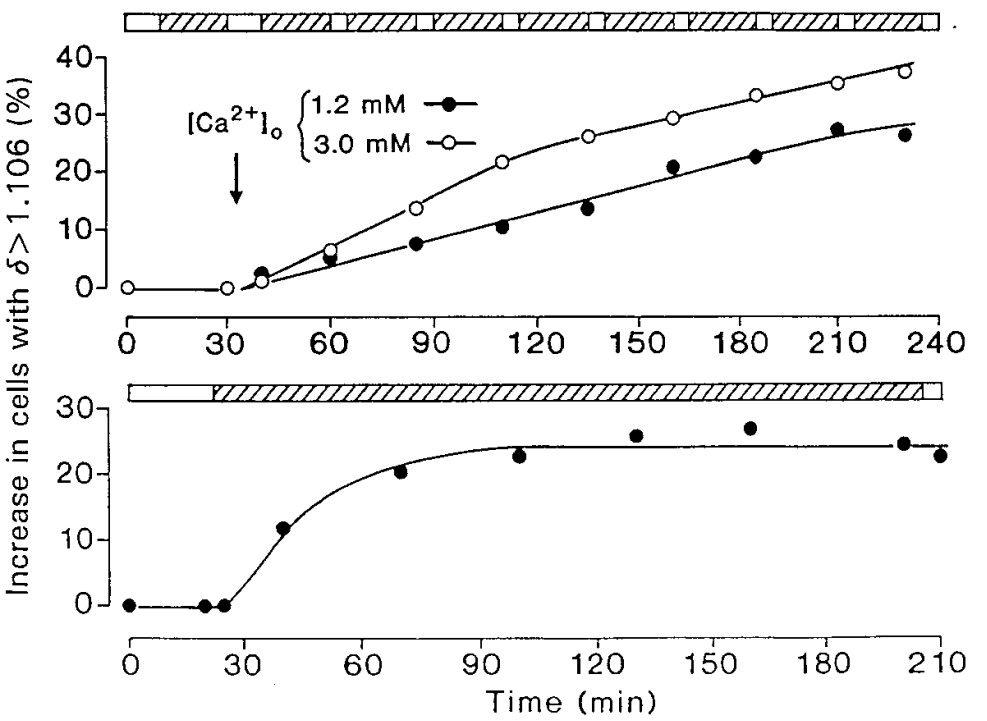

Figure 6. Effects of deoxy-oxy cycling and continuous deoxygenation on the density distribution of SS discocytes. In $A$ and $B$, cells suspended at $18 \% \mathrm{Hct}$ in solution $\mathrm{B}$ with adenine and inosine were tonometered at $37^{\circ} \mathrm{C}$, alternating deoxy ( $\left.20 \mathrm{~min}\right)$ and oxy $(5 \mathrm{~min})$ for $4 \mathrm{~h}$. After a first cycle in $\mathrm{Ca}^{2+}$-free media, either 1.2 or $3.0 \mathrm{mM} \mathrm{CaCl}_{2}$ was added. $A$ shows the density shifts in samples taken after each cycle and spun over the discontinuous arabinogalactan layers noted. The percentage of cells with $\delta>1.118$ after each oxy-deoxy cycle and with the two $\left[\mathrm{Ca}^{2+}\right]_{\mathrm{o}}$ levels is shown in $B$. In $C$, the proportion of cells with densities increased to $\delta>1.106$ after a single long deoxy pulse (bottom panel) is compared with that induced over time by the frequent deoxy pulsing protocol of $B$ (top panel). The cells in the bottom panel are from the same experiment as those of Fig. $2 \mathrm{~A}$.

values, $K_{\mathrm{Ca}}$ channel activation occurred with evidence of marked hyperpolarization, and was thus near maximal, a condition in which cell dehydration becomes rate-limited by $\mathrm{P}_{\mathrm{Cl}}$, which is fairly uniform in the cell population (25).

We consider now the relevance of these results to the process of SS cell dehydration in vivo. In this investigation, the new methods and experimental designs, together with the selection of SS discocytes, allowed a focused study of the dehy- dration process mediated by $\mathrm{K}_{\mathrm{Ca}}$ channels, with no interference from other mechanisms which may contribute to dehydration in vivo, that is, the $\mathrm{K}: \mathrm{Cl}$ cotransport and the $\mathrm{Na}$ pump. In SS reticulocytes and young red cells the $\mathrm{K}: \mathrm{Cl}$ cotransport accelerates dehydration according to its level of expression and activity (fast track cells) (21). On the other hand, $\mathrm{K}_{\mathrm{Ca}}$ channel-mediated dehydration operates in deoxygenated SS cells of all ages and densities. Therefore, although this study 


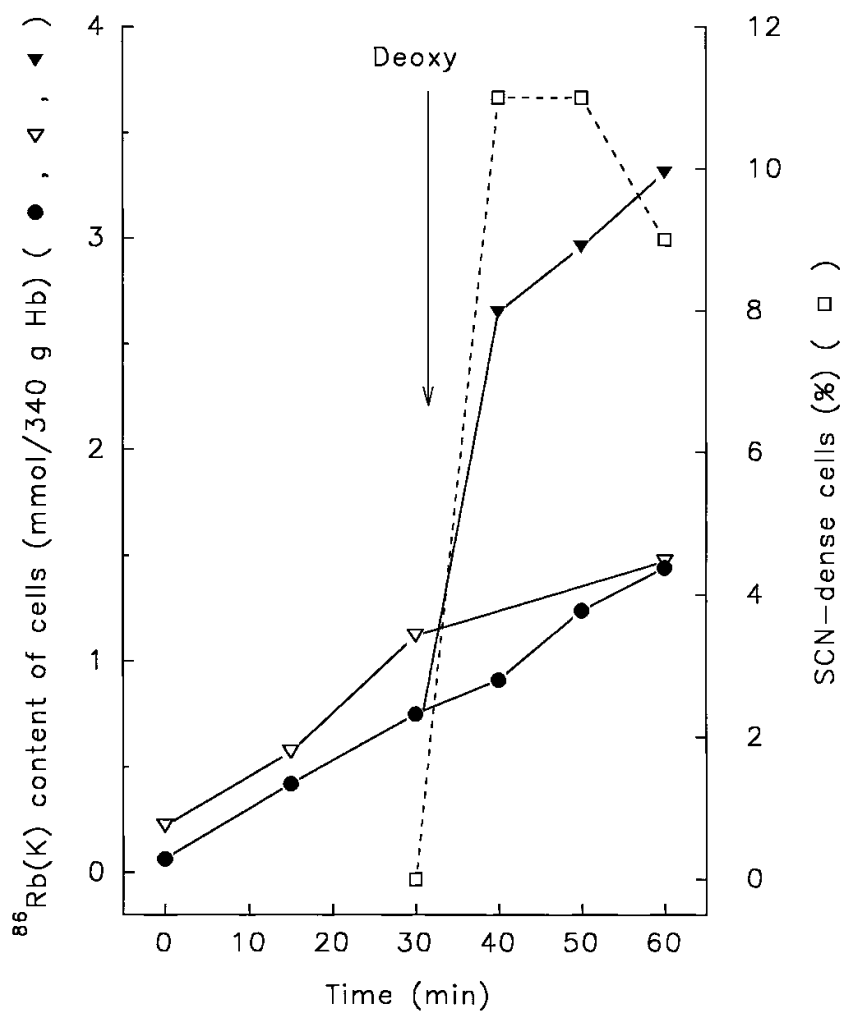

Figure 7. Effect of deoxygenation on $\mathrm{K}^{+}\left({ }^{86} \mathrm{Rb}\right)$ uptake by SCN-dense cells. SS discocytes, at $10 \%$ Hct in solution B with inosine and $1.6 \mathrm{mM}$ $\mathrm{CaCl}_{2}$, were incubated in the tonometer at $37^{\circ} \mathrm{C}$. At $t=0,{ }^{86} \mathrm{Rb}$ was added to give a specific activity of $10^{7} \mathrm{cpm} / \mu \mathrm{mol}$ of $\left[\mathrm{K}^{+}\right]_{\mathrm{o}}$. Samples were taken at the times shown for measurement of cell $\mathrm{K}^{+}\left({ }^{86} \mathrm{Rb}\right)$ content as previously described (18). The mean $\mathrm{K}^{+}\left({ }^{86} \mathrm{Rb}\right)$ content in the whole cell population is shown by the open triangles (oxy cells) and filled circles (cells deoxygenated at $t=30 \mathrm{~min}$ ). Filled triangles indicate the $\mathrm{K}^{+}\left({ }^{86} \mathrm{Rb}\right)$ content of the SCN-dense cells formed during deoxygenation (after $30 \mathrm{~min}$ ), the proportion of which is shown by the open squares.

centered on SS discocytes, the conclusions apply to $\mathrm{K}_{\mathrm{Ca}}$ channel-mediated dehydration in all SS cells.

An important new finding in this study is that deoxygenation-induced $\mathrm{Ca}^{2+}$ permeabilization of SS cells is a probabilistic event, with a distribution that includes a fraction of cells with $\mathrm{P}_{\text {sickle-Ca }}$ high enough for near-maximal $\mathrm{K}_{\mathrm{Ca}}$ channel activation in each deoxy pulse. In a population of deoxygenated $\mathrm{SS}$ cells, the probability is expressed as a distribution of $\mathrm{P}_{\text {sickle-Ca }}$ values. For an individual circulating SS cell, however, the probabilistic nature of $\mathrm{P}_{\text {sickle-Ca }}$ will be reflected in its different $\mathrm{P}_{\text {sickle-Ca }}$ value each time it becomes deoxygenated, with higher probabilities for low values. Although the dehydrating potential of each deoxy episode may be small, the cumulative effect of multiple episodes should lead to substantial cell dehydration, as indicated by the results in Fig. 6. However, except for cells trapped in stagnant capillary beds, the fraction of polymer-containing cells in the circulation at any time would be much smaller than that in the fully deoxygenated population in which the $\mathrm{P}_{\text {sickle-Ca }}$ distribution was measured here. Therefore, the true dynamic distribution of $\mathrm{P}_{\text {sickle-Ca }}$ among circulating SS cells would be a fraction of that inferred from the plateau dis- tribution in the tonometer (Fig. 5). The dehydration profiles obtained within 3-4 h in the tonometer (Fig. 6) may thus take much longer to develop in vivo, although the mechanism would be similar for those cells whose dehydration is mediated primarily by $\mathrm{K}_{\mathrm{Ca}}$ channels.

The possible nature of $P_{\text {sickle. }}$ With the limited state of present knowledge, these considerations must be highly speculative, but they may help formulate questions and working hypotheses for future experiments. Although it has yet to be established, we will assume for now that $\mathrm{P}_{\text {sickle-Ca }}$ reflects the

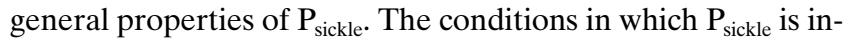
duced suggest that it somehow arises from interactions between deoxy-Hb $\mathrm{S}$ polymers and membrane components, which either generate a new transport pathway or modify a preexisting one. These polymer-cell membrane interactions may involve known or unidentified contacts. Let us consider what we can explain with known interactions to assess the need of unknown alternatives. One clearly identified configuration for the interaction between polymers and cytosolic membrane domains without cytoskeletal barriers is the protruding polymer spicule; in this configuration fiber surfaces and growing spikes could interact directly with the cytosolic aspect of freely diffusing membrane-embedded proteins (26).

Another documented interaction, between the red cell membrane and soluble hemoglobin, involves the $\mathrm{NH}_{2}$ terminus of band 3 protein and the central cavity of the deoxy-Hb tetramer (27). F.A. Ferrone suggested that this restraining reaction might provide a site energetically favorable for nucleation (personal communication). If deoxy-Hb S polymers participate in this link, bundles of adjacent fibers might generate local areas of high density links with band 3 protein, forming oligomeric aggregates of the band 3 dimers, which could function as a large ion channel. The inhibitory effects of stilbenes on $\mathrm{P}_{\text {sickle }}(7)$, though not specific, would be consistent with such a participation of band 3 protein in the structure of the $P_{\text {sickle }}$ pathway. In this context it is of interest to note that although $\mathrm{P}_{\text {sickle }}$ is recognized as a poorly selective cation channel, its lack of selectivity may extend to anions as well. Its structure might then resemble that recently suggested for anion-channel-forming trout band 3 protein when expressed in xenopus oocytes (28).

With these possibilities in mind, we now ask what insights the present experiments may provide on the properties of $\mathrm{P}_{\text {sickle. }}$ Initiation of sickle polymer formation by nucleation is a random process with a skewed time-dependent distribution and a $50^{\text {th }}$ order reaction mechanism (29). Once polymerization is initiated within a particular cell, progression to polymer solubility equilibrium $\left(\mathrm{C}_{\mathrm{sat}}\right)$ with soluble deoxy-Hb S should be quite rapid. The kinetics of cell recruitment to the fully polymerized equilibrium condition (equivalent to the kinetics of sickling) in the present experiments could therefore be inferred from the time course with which the fraction of SCNdense cells approached its plateau level (Figs. 1, 2, and 4, A and $C$ ). This kinetics was apparently somewhat variable, which could reflect $(a)$ the intrinsic random distribution of nucleation times (Ferrone); $(b)$ cell to cell differences in Hb concentration of up to $4 \mathrm{~g} / \mathrm{dl}$ within the discocyte density fraction used here; $(c)$ the presence of fetal hemoglobin-containing cells (F-cells), likely to be either the slowest recruits observed here at high $\mathrm{Ca}^{2+}$ levels (Fig. 4, $A$ and $C$ ), or cells generating no polymer and no $\mathrm{P}_{\text {sickle }}$; and $(d)$ differences in deoxygenation rates in the tonometer, due to different hematocrits, total volumes, or minor $\mathrm{pH}$ differences. As previously observed with 
the same tonometry system (30), extensive polymerization/ sickling appears to have been attained within $\sim 30 \mathrm{~min}$ in most conditions (see delays to plateau in Figs. 2, 4, $A$ and $C$ ), evoking the participation of at least $60-70 \%$ of cells in SCN-dense cell formation at sufficiently high $\mathrm{Ca}^{2+} .2$ At equilibrium, as in the plateau phase of SCN-dense cell formation, all the permeabilizing contacts between polymers and the relevant membrane domains must have been established. If we assume that each effective contact generates a quantum of permeabilization, and therefore that cell to cell differences in $\mathrm{P}_{\text {sickle }}$ may be due simply to differences in the number of permeabilizing contacts, the results suggest that $(a)$ the number of permeabilizing contacts established in each deoxy pulse is random and variable from pulse to pulse in each cell; $(b)$ for the duration of the deoxy pulse, the permeabilizing contacts must either become established during the brief polymer formation phase and remain structurally stable, or they may result from reversible interactions, with different equilibrium levels in each cell during different deoxy pulses; and $(c)$ the stochastic variability of permeabilizing contacts in each pulse is the result of random fluctuations in either the formation of the stable polymer contacts, or in the concentration of available interactive polymer contacts (surfaces, ends, or spicules) which form in each pulse; for the concentration and accessibility of membrane targets, whether immobilized by cytoskeletal links or in free lateral diffusion, should not exhibit random variation between pulses.

Several of the speculative assumptions in this account are amenable to experimental testing, using systems such as cytoskeleton-free, $\mathrm{Hb}$-S-containing vesicles derived from isolated spicules, known to contain the proposed reactive components of the permeabilizing contacts (26). Investigation of cation transport and structural changes in such vesicles in oxy and deoxy conditions is currently in progress.

2. The kinetics of red cell deoxygenation and oxygenation in the IL tonometer in vitro must be less efficient than that of red cells squeezing through capillaries, where gas equilibration times and diffusion through unmixed layers surrounding the cells are minimized. Thus the time required for polymer equilibration and maximal activation of $\mathrm{P}_{\text {sickle }}$ in vivo should be considerably shorter than in this in vitro system.

\section{Acknowledgments}

We wish to thank the Wellcome Trust (United Kingdom), The British Heart Foundation, and the National Institutes of Health (grants HL28018 and HL-20985) for funds.

\section{References}

1. Tosteson, D.C., E. Carlsen, and E.T. Dunham. 1955. The effects of sickling on ion transport. I. Effect of sickling on potassium transport. J. Gen. Physiol. 39:31-53.

2. Tosteson, D.C. 1955. The effects of sickling on ion transport. II. The effect of sickling on sodium and cesium transport. J. Gen. Physiol. 39:55-67.

3. Eaton, J.W., T.D. Skelton, H.S. Swofford, C.E. Koplin, and H.S. Jacob. 1973. Elevated erythrocyte calcium in sickle cell disease. Nature (Lond.). 246: 105-106.
4. Palek, J. 1977. Red calcium content and transmembrane calcium movements in sickle cell anemia. J. Lab. Clin. Med. 89:1365-1374.

5. Bookchin, R.M., and V.L. Lew. 1978. Effects of a "sickling pulse" on the calcium and potassium permeabilities of intact, sickle trait red cells. J. Physiol. (Lond.). 284:93P.

6. Ortiz, O.E., V.L. Lew, and R.M. Bookchin. 1990. Deoxygenation permeabilizes sickle cell anaemia red cells to magnesium and reverses its gradient in the dense cells. J. Physiol. (Lond.). 427:211-226.

7. Joiner, C.H. 1990. Deoxygenation-induced cation fluxes in sickle cells. II. Inhibition by stilbene disulfonates. Blood. 76:212-220.

8. Bookchin, R.M., O.E. Ortiz, and V.L. Lew. 1987. Red cell magnesium content and permeability in sickle cell anemia. Clin. Res. 35:651. (Abstr.)

9. Etzion, Z., T. Tiffert, R.M. Bookchin, and V.L. Lew. 1993. Effects of deoxygenation on active and passive $\mathrm{Ca}^{2+}$ transport and on the cytoplasmic $\mathrm{Ca}^{2+}$ levels of sickle cell anemia red cells. J. Clin. Invest. 92:2489-2498.

10. Tiffert, T., J.L. Spivak, and V.L. Lew. 1988. Magnitude of calcium influx required to induce dehydration of normal human red cells. Biochim. Biophys. Acta. 943:157-165.

11. Lew, V.L., A. Hockaday, M.I. Sepulveda, A.P. Somlyo, A.V. Somlyo, O.E. Ortiz, and R.M. Bookchin. 1985. Compartmentalization of sickle cell calcium in endocytic inside-out vesicles. Nature (Lond.). 315:586-589.

12. Garcia-Sancho, J., and V.L. Lew. 1988. Detection and separation of red cells with different calcium contents following uniform calcium permeabilization. J. Physiol. (Lond.). 407:505-522.

13. Ferreira, H.G., and V.L. Lew. 1976. Use of ionophore A23187 to measure cytoplasmic $\mathrm{Ca}$ buffering and activation of the $\mathrm{Ca}$ pump by internal $\mathrm{Ca}$. Nature (Lond.). 259:47-49.

14. Lew, V.L., R.Y. Tsien, C. Miner, and R.M. Bookchin. 1982. The physiological $\left(\mathrm{Ca}^{2+}\right)$ level and pump-leak turnover in intact red cells measured with the use of an incorporated Ca chelator. Nature (Lond.). 298:478-481.

15. Tiffert, T., and V.L. Lew. 1997. Cytoplasmic calcium buffers in intact human red cells. J. Physiol. (Lond.). In press.

16. Payne, J.A., C. Lytle, and T.J. McManus. 1990. Foreign anion substitution for chloride in human red blood cells: effect on ionic and osmotic equilibria. Am. J. Physiol. 259:C819-C827.

17. Wieth, J.O. 1969. Effects of bicarbonate and thiocyanate on fluxes of $\mathrm{Na}$ and $\mathrm{K}$, and on glucose metabolism of actively transporting human red cells. Acta Physiol. Scand. 75:313-329.

18. Ortiz, O.E., V.L. Lew, and R.M. Bookchin. 1986. Calcium accumulated by sickle cell anemia red cells does not affect their potassium $\left({ }^{86} \mathrm{Rb}\right)$ flux components. Blood. 67:710-715.

19. Tiffert, T., Z. Etzion, R.M. Bookchin, and V.L. Lew. 1993. Effects of deoxygenation on active and passive $\mathrm{Ca} 2+$ transport and cytoplasmic $\mathrm{Ca} 2+$ buffering in normal human red cells. J. Physiol. (Lond.). 464:529-544.

20. Bookchin, R.M., O.E. Ortiz, A.V. Somlyo, A.P. Somlyo, M.I. Sepulveda, A. Hockaday, and V.L. Lew. 1985. Calcium-accumulating inside-out vesicles in sickle cell anemia red cells. Trans. Assoc. Am. Physicians. 98:10-20.

21. Bookchin, R.M., O.E. Ortiz, and V.L. Lew. 1991. Evidence for a direct reticulocyte origin of dense red cells in sickle cell anemia. J. Clin. Invest. 87: 113-124.

22. Clark, M.R., J.C. Guatelli, N. Mohandas, and S.B. Shohet. 1980. Influence of red cell water content on the morphology of sickling. Blood. 55:823-830.

23. Mohandas, N., M.E. Rossi, and M.R. Clark. 1986. Association between morphological distortion of sickle cells and deoxygenation-induced cation permeability increase. Blood. 68:450-454.

24. Glynn, I.M., and A.E. Warner. 1972. Nature of the calcium dependent potassium leak induced by (+)-propranolol, and its possible relevance to the drug's antiarrhythmic effect. Br. J. Pharmacol. 44:271-278.

25. Raftos, J.E., R.M. Bookchin, and V.L. Lew. 1996. Distribution of chloride permeabilities in normal human red cells. J. Physiol. (Lond.). 491:773-777.

26. Allan, D., A.R. Limbrick, P. Thomas, and M.P. Westerman. 1982. Release of spectrin-free spicules on reoxygenation of sickled erythrocytes. Nature (Lond.). 295:612-613.

27. Walder, J.A., R. Chatterjee, T.L. Steck, P.S. Low, G. Musso, E.T. Kaiser, P.H. Rogers, and A. Arnone. 1984. The interaction of hemoglobin with the cytoplasmic domain of band 3 of the human erythrocyte membrane. J. Biol. Chem. 259:10238-10246.

28. Fievet, B., N. Gabillat, F. Borgese, and R. Motais. 1995. Expression of band 3 anion exchanger induces chloride current and taurine transport: structure-function analysis. EMBO (Eur. Mol. Biol. Organ.) J. 14:5158-5169.

29. Cao, Z.Q., and F.A. Ferrone. 1996. A 50th order reaction predicted and observed for sickle hemoglobin nucleation. J. Mol. Biol. 256:219-222.

30. Bookchin, R.M., T. Balazs, and L.C. Landau. 1976. Determinants of red cell sickling. Effects of varying $\mathrm{pH}$ and of increasing intracellular hemoglobin concentration by osmotic shrinkage. J. Lab. Clin. Med. 87:597-616. 